\title{
Európai uniós integrációs modellek
}

Halmai Péter (szerk.): Tagállami integrációs modellek-A gazdasági kormányzás új dimenziói az Európai Unióban. Budapest: Dialóg Campus, 2019. 277 o. https://doi.org/10.47707/Kulugyi Szemle.2021.1.9

A Halmai Péter szerkesztésében megjelent tanulmánykötet a Nemzeti Közszolgálati Egyetemen múködő Ludovika Kiemelt Kutatómủhely „A modern állam gazdasági szerepének legújabb dimenziói” elnevezésú, széles körú kutatásain alapul. A mú a differenciált integráció, a többsebességes Európa témakörének a fó irányzatait, időszerủ fejleményeit multidiszciplináris megközelítésben tárgyalja. A szerzők között az érintett tudományterületek, mindenekelótt a jog, a közgazdaságtan, a nemzetközi és az Európa-tanulmányok jeles művelői szerepelnek.

A kötet a bevezetővel együtt összesen tizenhárom fejezetet tartalmaz. E tanulmányok, ahogyan az a szerkesztői előszóban, illetve a bevezető fejezetben (.,Bevezetés: tagállami integrációs modellek”, 15-26. o.) is olvasható, jellemzően a következő témák áttekintésére és elemzésére irányulnak: az euróövezeten kívüli és belüli tagállamok eltérô pozíciói és perspektívái az integráció rendszerében; az európai gazdasági kormányzástól várható intézményi változások; a tagállami jogalkalmazás eltérései; a megerősített együttmúködésben rejlő lehetôségek; a legnagyobb és legbefolyásosabb tagállamok helyzete; a mediterrán és a kelet-közép-európai perifériaállamok körülményei; valamint az euroszkeptikus irányzatok újjászüiletésének a lehetséges következményei.'

Palánkai Tibor tanulmánya („Integráció és kohézió az EU-ban”, 27-50. o.) a többsebességes Európai Unió lehetőségét az integráció

\footnotetext{
1 A kötetben terjedelmi okokból nem szenteltek külön fejezetet a brexit különösen bonyolult témakörének. Ugyanakkor a mű alapját képező kutatás során behatóan vizsgálták az Egyesüilt Királyság kilépésének a problémakörét. Ld.: Halmai, 2018.: Halmai. 2020a; Halmai, szerk., 2020; Halmai, 2020b.
} 
és a kohézió fogalmainak történelmi igényű összevetéséből vezeti le: meghatározott irányzatok és bizonyos történések, így a 2008-as válság és annak következményei, valamint a globalizáció és a technológiai fejlődés kedvezőtlenebb hatásai az integráció elmélyüilése ellen fejthetnek ki hatást, az Európai Unió kohéziós válságának pedig elsősorban a mediterrán régióban található tagállamok az elszenvedỏi. A szerző a jövő szempontjából a legújabb kihívásoknak megfelelően megújított európai ökoszociális piacgazdaság modelljét tekinti a legmegfelelőbbnek, ,amely a társadalom valamennyi tagja számára a tisztes jólét elérését, »emberléptékű életviszonyok« kialakítását tűzné ki célul" (48. o.).

Koller Boglárka tanulmánya (,Többsebességes vagy menüválasz tásos jövő?", 51-65. o.) a differenciált integráció elméleti és gyakorlati kérdéseivel foglalkozik. Áttekinti a fogalom evolúcióját, küiönös hangsúllyal a megerősített egyuittmúködés intézményére, valamint a differenciált integrációnak az EU elsődleges jogában megjelenő formájára. A szerző összeveti a differenciált integrációnak a többsebességes, az à la carte és a változó geometriájú altípusait. Végüil áttekinti a differenciált integrációnak az Európai Unióra gyakorolt hatásait.

Halmai Péter tanulmányában („Differenciált integráció: gazdasági integrációs modellek", 67-142. o.) szintén a differenciált integráció a vizsgálat tárgya, ám azt a szerző a gazdasági integráció oldaláról veszi górcső alá. Ugyanakkor a problémakör átfogó elemzése lényeges, általánosabb érvényú megállapításokhoz is megfelelô alapot kínált. ${ }^{2} \mathrm{~A}$ teljes körű interpretációt és elemzést követően a szerző válságközpontú megközelítésben tárgyalja a témát: a Gazdasági és Monetáris Unió esetében az euróövezet krízisét, a schengeni rendszerében pedig a migránsválság miatt kialakult veszélyhelyzetet állítja a középpontba.

A differenciált integráció rendszerszintű analízise alapján a tanulmány fő megállapítása:

.A kölcsönös függöség és az átpolitizáltság a differenciált integráció fö hajtóerôi . Növekvő kölcsönös függőség teremti meg a nagyobb integráció igényét. Ameddig az integráció nem a »mag« állami

2 Az átfogó koncepcionális keretekről ld.: Halmai, 2013; Halmai, 2020c; Halmai, 2020d. 


\section{Külïgyi Szemle}

hatalomra, illetve az integrációt erősen igénylő országokra kor látozódik, az integráció valószínúleg elkerülheti az átpolitizáltságot, és egységes (unitárius) maradhat. Ez volt az európai in tegráció általános iránya az 1980-as évek végéig. A kölcsönös függőség nyomásának növekedésével párhuzamosan jelenik meg az átpolitizáltság. Az különösen az állami „mag”-hatalom kulcs terüiletei és a kevésbé integrációbarát országok esetében fejthet ki erőteljes hatást. Ez a helyzet jellemző 1990 után. A részben bizonyos mértékig euroszkeptikus közvéleménnyel jellemezhető tagállamok megkérdőjelezik az európai integráció magállamai által szorgalmazott nemzetek feletti integrációt. Ez belső diffe renciálást eredményez. Ahol az euroszkepticizmus erős beágyazottsága meghiúsítja a csatlakozást, a nem átpolitizált területek magas fokú kölcsönös függósége alapján a belső piachoz történő szelektív integrációval reagálnak. E folyamat külsó differenciálást eredményez.

A differenciálás alapja az exogén és endogén kölcsönös függés to vábbi növekedése. A legutóbbi pénzügyi és gazdasági krízis, illetve azon belüi a szuverén adósságválság során szerzett tapasztalatok szerint mind a kölcsönös függóség nyomása, mind az integ ráció átpolitizáltsága tartósan érvényesüilő sajátosság. E ténye zők mélyíthetik a különbséget az euróövezet és az Európai Unió többi része között. Kiterjedhetnek az újabban integrált politikai területekre (például a bankszabályozásra)... Az externalitások a külső differenciálás iránt állandó igényt eredményeznek." (Halmai, szerk., 2019. 18. o.)

„A tagállamok megegyezésén alapuló, differenciált integráció pragmatikus, második legjobb megoldás. Annak minden EU-tag előtt nyitva kell állnia. A differenciálás módszere egyes szakpolitikák terén alkalmazható, átmeneti konstrukció a hatékonyabb és egységes döntéshozatal felé vezető úton. Nem léphet az egyre szorosabb Unió (a mély integráció rendszere) kiépitése folyamatá nak helyébe. Nem vezethet első- és másodrangú EU-tagság kialakulásához. Végső célja a befogadás előmozdítása, nem pedig a 
tagállamok kizárása. További, elkerülendő veszélyek a politikai és intézményi fragmentáció, illetve a döntéshozatali folyamat még bonyolultabbá válása." (Halmai, szerk., 2019. 105. o.)

A tanulmány záró alfejezetében a szerző a Gazdasági és Monetáris Unió (GMU) reformjának, a GMU 2.0-nak a lehetséges fô irányait tekinti át.

„A teljes gazdasági unió, az európai gazdasági kormányzás kiépülése valódi esélyt kínál az európai gazdaság problémáinak megoldására, egyúttal a teljes európai integrációs folyamat dinamizálására. Mindennek előfeltétele a hatáskörök újraszabályozása, s ahol szükséges, az érintett tagállamok érdekein és önálló döntésén alapuló további szuverenitástranszfer. Arról természetesen az egyes tagországok eltérően is vélekedhetnek." (Halmai, szerk., 2019. 136. o.)

Benczes István tanulmánya (.,Maastrichti kompromisszum: vele vagy nélküle?", 143-165. o.) szintén a tervezett uniós reformokkal foglalkozik, mégpedig a pénzügyi szabályok várható szigorításával és a leendő fiskális unió lehetőségeivel:

„Habár a gazdasági kormányzás reformjának többszintủ igé nye, sőt konkrét ötletei is megfogalmazódtak 2010 után, Európa vezetői érzékelhetően és érdemben a szabályok erősítése mellett kötelezték el magukat. A hatos törvénycsomag, illetve különösen a fiskális paktum az úgynevezett »maastrichti kompromisszum továbbélését jelenítik meg, azaz a nemzetek feletti (szupranacionális), illetve a nemzetállami szintek közötti kompetenciamegosztást erősítik. Ugyanakkor abban talán egységesnek mondható az Unió, hogy a GMU monetáris pillére kiegészítéseként szükségszerüen ki kellene építeni a most még hiányzó gazdasági pillért is. Ennek legfôbb eleme a fiskális unió lehetne, ami a maastrichti kompromisszum - legalább részleges - felmondását (is) jelentené a jövőben.

A 2008-ban Európát is elérő adósságválság nyomán az Európai Unió most egyszerre kívánja korlátozni újabb szabályok által a 


\section{Külïgyi Szemle}

fiskális politika mozgásterét és növelni annak rugalmasságát a közösségi szintű költségvetési politika határainak (és nagyságának) kiterjesztésével. Míg azonban a fiskális szabályok szigorítá sával, majd tagállami szintú kötelező érvényú birtokbavételével konkrét lépéseket is tett az Unió, addig az intézményi reformo kat megjeleníteni hivatott fiskális unió jobbára még mindig csak ötlet, jó esetben terv maradt. Ugyan az elmúlt 2-3 esztendóben újra felélénkülni látszik a vita a valós közösségi szintű intézményi reformok keresztülviteléről, és egyben annak lehetősége is látszódni kezd, hogy az intézményi integráció elmélyítése egyszer smind a túl bonyolulttá vált szabályrendszer egyszerúsítéséhez is teret biztosithat, ám a tényleges tetteket továbbra is középtávra teszi az EU." (Halmai, szerk., 2019. 20. o.)

A tanulmány kritikusan szemléli a fiskális unió megteremtésének a lehetőségét. „A fiskális unió - ha lesz is - nem valószínű, hogy nagyobb lenne, mint a tagok GDP-jének 1,5-2\%-a, és mint ilyen, nem lehet majd több alkalmi stabilizációs eszköznél, amelyet csak kivételes esetekben aktiválnak a felek." Azaz távol áll még Brüsszel attól, hogy a fiskális unió révén a tagállamok egy leendô politikai unió alapjait teremthetnék meg. Így a Maastrichtban tető alá hozott kompromiszszumos szerzôdés reformját célul ki lehet tûzni ugyan, de a tényleges megvalósításra minden bizonnyal éveket kell még várni.

Csaba László az írásában („A költségvetési és bankunió: vízválasztó a többsebességes EU-ban”, 167-182. o.) az előző fejezetben tárgyalt fiskális unióval kapcsolatos problémákat boncolgatja tovább. A szerzô a témával már nem elsô ízben foglalkozott, hiszen nem sokkal az után, hogy az Európai Tanács akkori elnöke, Hermann van Rompuy nyilvánosságra hozta a költségvetési és bankunió megvalósítását előirányzó tervet, igyekezett bemutatni egyrészt a föderális EU-ban rejlő lehetőségeket, másrészt az addig még az EU előtt tornyosuló akadályokat (Csaba, 2013). A most ismertetendő tanulmányában

„arra a kérdésre keresi a választ, hogy a Költségvetési és Bankunió (a továbbiakban: KBU) eddigi múködési tapasztalatai és a vár ható kiegészítő intézkedések mennyiben jelentenek új szakaszt 
az európai integráció fejlődésében. Megállapítja, hogy a nemzetek fölötti döntéshozatalnak olyan új rendje jött létre, amelyből csak a brexit révén lehet kilépni. Ezzel szemben a »kívüil is levók, belül is levők számára a költségek halmozódnak, míg a haszon elmarad. A KBU a többsebességes Európa korábban is létezett gyakorlatát formális-intézményi szintre emeli. A kimaradókra az örök cserejátékos szerepe vár, pénzügyi sérülékenységgel és az érdemi nagy döntésekből történő intézményes kimaradással.

A közvetlen válságon ugyan már túl van az euróövezet, ám az Európai Unió továbbra is kénytelen napirenden tartani a gazdasági kormányzás reformját. E reform - más és más intenzitással és eredménnyel - jelenleg négy területre koncentrál, ezek: 1. a fiskális politikai fegyelem numerikus szabályok által történő erősítése; 2. a hatékony válságrendezés mechanizmusainak lefektetése; 3. közös felelősségvállalás megteremtése a tagországok államadósságaira (vagy azok egy részére); valamint 4. a fiskális unió létrehozása.

Az Európai Unió alapjaiban alakult át a 2008-2012-es idószak válságkezeló intézkedései hatására. Egyfelől jelentősen megnőtt a nemzetek fölötti, technokratikus döntések súlya a kormányköziek ellenében. Míg a politika terén - különösen a külpolitikában és az igazságügyi együttmúködésben - a kormányköziség szilárdan tartja magát, a pénzről egyre inkább független szabályozó hatóságok és közvetlen politikai elszámoltathatósággal nem bíró testületek döntenek. (Az ilyen módon elköltött összegek a hagyományos ágazati együttmúködési keretek többszörösét teszik ki.)" (Halmai, szerk., 2019. 20-21. o.)

A szerző szerint a többsebességes Európa ma már nem veszély, hanem tény:

„Az euróövezetben új minőségű, szupranacionálissá mélyüilt in tegráció jött létre. Ugyanakkor a tagállamok egy része... saját dön tés alapján kimaradt. Nem vettek részt az új szabályok megalkotásában, és így nem élvezik majd az ezáltal létrejött védőernyőt a bizonyára bekövetkező legközelebbi pénzügyi válság idején. 


\section{Külïgyi Szemle}

A bankfelügyelet nemzetek fölötti szintre kerülése... meggyengí tette a kontinentális banki modell egyik alapvonását: a tulajdonos és szabályozó állam[, valamint] - az elvileg piaci elveket követő - bankjai közti meghitt viszonyt." (Halmai, szerk., 2019. 21. o.)

Másfelől viszont ugyanez a folyamat piacelvúbb és technokratább felügyeletet hozott létre, ám „aki kimarad, az lemarad... [így a] bankrendszere és valutája ellen bizonyára sokkal kisebb költséggel lehet támadást intézni." (Halmai, szerk., 2019. 21. o.)

Kutasi Gábor az ökonometriai módszerekre is támaszkodó tanulmányában („Küilső egyensúlytalanság az euróövezetben. Megoldás-e a többszintủ kormányzás?”, 183-196. o.) az euróövezetben jelentkező külső egyensúlytalanságot állítja a középpontba. A fiskális uniót aszimmetrikus fiskális kockázatközösségként jellemzi. Az egyenlőtlenségek pedig megoldást igényelnek, akár a többszintű kormányzás lehetősé geinek a felhasználásával is. Az egyes tagállamok deficitfinanszírozá sát más tagállamokra terhelő eurokötvények kibocsátásával kapcso latban lényeges fenntartásokat fogalmaz meg. Nyilvánvalóan ,jelentős erkölcsi kockázatot hordoz magában, ha egyes tagállamok bátorítást éreznek arra, hogy a fiskális kockázatközösséget egyfajta végső hite lezőnek tekintsék." (Halmai, szerk., 2019. 194. o.)

Győrffy Dóra írása („Erkölesi kockázat és szolidaritás a GMU-ban: a görög válság tanulságai”, 197-208. o.) a szuverén adósságválság időszakában különösen gyakran emlegetett „grexit” témakörét elemzi. A 2008-2009-es válság, majd az azt követő szuverén adósságkrízis következtében olyan, korábban szinte tabuként kezelt megállapodás vált semmissé a Gazdasági és Monetáris Unió kapcsán is, mint a „no bailout”, a „nincs kimentés” szabálya is. E tabudöntések - amelyek Görögországgal, illetve annak helyzetével kapcsolatban voltak a leglátványosabbak - a szolidaritás elvének az erkölcsi kockázat feletti gyơzelmét mutatják. Elméletileg felmerülhet ugyanakkor akár Görögország kilépésének a lehetősége is, mint távlati „megoldás”. A brexit mintájára ez lett a grexit, amelynek esélyeit és buktatóit a tanulmány behatóan elemzi. A komplex áttekintés eredményeképpen a szerző 
megállapítja: a grexit hiábavalónak és valószínútlennek minősíthető. Az EU-ban maradás viszont Görögország és az Európai Unió részéről áldozatokkal is jár, s egyben kikényszeríti a szupranacionális szint növekvő szerepét.

Kecskés László „A jogharmonizáció integráló erejének gyengülése” címú tanulmánya (209-228. o.) jogi szempontból, de történeti igénynyel tárja fel a kérdéskört az integráció kezdetétől napjainkig. Meggyőzően érvel amellett, hogy az 1990-es évek elejéig a jogharmonizációnak egyértelműen az integrációt erôsítő szerepe volt. Az Európai Bíróság az 1991-es Frankovich-ítéletben még a tagállami kárfelelősség alkalmazhatóságát is felvetette, azonban ezt követően, az ún. „posztFrankovich érában" már sokkal bizonytalanabban nyilatkozott. A nagy kiterjedésú keleti bővítések a munkáját „nagyüizemivé” tették, s a vonatkozó gondolatok kevésbé kidolgozottan jelentek meg. Ugyanakkor a jogharmonizáció célkitűzése a lisszaboni szerződésben is egyértelmûen benne maradt.

Király Miklós tanulmánya („A nemzetközi magánjog kodifikálá sának útjai az Európai Unióban és tagállamaiban”, 229-235. o.) az uniós tagállamok nemzetközi magánjogi jogegységesítési tendenci áit tekinti át.

Várkonyi László két tanulmánya is szerepel a kötetben, amelyek közül az első az „Intézményközi harcok az EU kereskedelempolitikai döntéshozatali, jogalkotási folyamataiban" címet viseli (237-247. o.). A lisszaboni szerződés jelentősen átrendezte az EU-n belüli erőviszonyokat. „A közösségi kompetencia egyre szélesebb területre való kiterjesztése önmagában is fokozta a Bizottság és a Tanács közötti feszülltségeket, az EP érdemi szereplővé válása pedig új dimenziót adott az intézmények közötti küzdelemnek" (Halmai, szerk., 2019. 245. o.). A 2008 -as válság pedig a protekcionizmus erősödéséhez és a Kereskedelmi Világszervezet (WTO) globális gazdasági liberalizációs törekvéseinek a háttérbe szorulásához vezetett. Megnőtt a társadalmaknak a tárgyalási folyamatok átláthatósága iránti igénye, s ezt az Európai Parlament nyomására - a társadalmi támogatottság érdekében - a Bizottság és a Tanács igyekszik is biztosítani. A folyamat egyértelmű nyertese az Európai Parlament lett. 


\section{Külïgyi Szemle}

A szerző a második tanulmányában („Lisszaboni Szerződés: EU-s és tagállami beruházási hatáskörök”, 263-277. o.) szintén a - lisszaboni szerződés által módosított - közös kereskedelempolitika terén tesz megállapításokat, elsősorban a beruházások kapcsán.

„Az Európai Bizottság alapvetően a szolgáltatások kereskedel mét és a beruházásokat (gazdasági célú letelepedést) érintő WTO-tárgyalásokkal összefüggésben, az egységes EU-fellépés érdekében igényelte a nemzetközi beruházási kapcsolatok szabályozására vonatkozó kizárólagos közösségi kompetencia rög zitését. A több évtizedes folyamatos bizottsági törekvés végül eredményre vezetett." (Halmai, szerk., 2019. 26. o.)

A beruházásvédelem és a tagállamok közti számos bilateral investment treaty (BIT) tekintetében még vannak nyitott kérdések, különösen az átláthatóság és a választottbíróságok pártatlan jogszolgáltatása kapesán. Az EU és Kanada közti átfogó gazdasági és kereskedelmi megállapodás (CETA) körüil a belga szövetségi kormány és Vallónia között kialakult feszültségeket csak az Európai Bizottság részvételének a garantálásával sikerüilt lecsillapítani.

Hetényi Géza a tanulmányában (.Többsebességes Európa Magyar érdekek a Gazdasági és Monetáris Unió mélyítése során”, 249-262. o.) a szerzô átfogóan elemzi a monetáris és fiskális pillér hazánkra gyakorolt hatásait, valamint az euróövezethez történő jövőbeli csatlakozás érdekében megnyugtatóan megválaszolandó kér déseket.

A kötet tanulmányai sok irányból, többféle szemszögből világítják meg az európai integráció alapvető szerkezetét, a tagállami integráció mechanizmusait, azon belül kiemelt figyelemmel a differenciált integráció rendszerét. A mú az alapvető kérdések logikus rendszere zése és mélyebb elemzése mellett különös figyelmet fordít az integráció nyitott kérdései azonosítására, a jövőbeli lehetséges irányzatok 
bemutatására. A könyv biztonsággal ajánlható az európai integráció témakörei iránt érdeklődő szakemberek és a szélesebb olvasóközönség számára egyaránt.

Vasa László

\section{Irodalomjegyzék}

Csaba László (2013). Európai Egyesült Államokat - de most rögtön? Köz Gazdaság, 8(1). 19-27.

Halmai Péter (2013). Európai integráció és szuverenitás: A gazdasági kormányzás új dimenziói. Magyar Tudomány, 174(4). 411-421.

Halmai Péter (2018). A Brexit lehetséges gazdasági hatásai. Európai Tükör, 21(2). 7-32.

Halmai Péter (2020a). A dezintegráció gazdaságtana. A brexit esete. Közgazdasági Szemle, 67(9). 837-877.

Halmai Péter (2020b). A populizmus ára: a brexit-adó. Magyar Tudomány, 181(12). 1621-1635.

Halmai Péter (2020c). Európai gazdasági inlegráció. Budapest: Ludovika Egyetemi Kiadó.

Halmai Péter (2020d). Mélyintegráció. A Gazdasági és Monetáris Unió ökonómiája. Budapest: Akadémiai Kiadó.

Halmai Péter (szerk.), (2019). Tagállami integrációs modellek. A gazdasági kormányzás új dimenziói az Európai Unióban. Nemzeli Közszolgálali Egyelem Államludományi és Nemzetközi Tanulmányok Kar. A letöltés ideje: 2021. április 7. https://antk.uni-nke.hu/document/akk-copv-uninke-hu/web_PDF_Tagallami integracios modellek.pdf.

Halmai Péter (szerk.), (2020). A brexit forgatókönyvei és hatásai. Budapest: Nordex Nonprofit Kft. - Dialóg Campus Kiadó. 